\title{
Laparoscopic cystotomy for urolith removal in dogs: three case reports
}

\author{
[Cistotomia laparoscópica na remoção de urólitos em cães: relato de três casos] \\ M.V. Brun ${ }^{1}$, S.T. Oliveira ${ }^{2}$, S.A. Messina ${ }^{1}$, R. Stedile ${ }^{2}$, R.P. Oliveira ${ }^{1}$ \\ ${ }^{1}$ Universidade de Passo Fundo \\ Bairro São José - BR 285 - Km 171 \\ Caixa Postal 611/631 \\ 99001-970 - Passo Fundo, RS \\ ${ }^{2}$ Universidade Federal do Rio Grande do Sul - Porto Alegre, RS
}

\begin{abstract}
The use of laparoscopic surgery for the removal of cystic calculi in three dogs was reported. Three trocars were used, one in the ventral midline $(10 \mathrm{~mm})$ and the others in the right $(10 \mathrm{~mm})$ and left $(5 \mathrm{~mm})$ flanks. The calculi were removed and the bladder was sutured with intracorporeal technique in two layers, a simple continuous pattern and interrupted or continuous Lembert pattern. No postoperative complications were observed. One patient had a recurrence of urolithiasis, attributed to inadequate conservative treatment and to the lack of an appropriate diet. It was submitted to another similar videolaparoscopic cystotomy without complication. The proposed technique is appropriate and an alternative to conventional cystotomy for treatment of canine vesical urolithiasis.
\end{abstract}

Keywords: dog, laparoscopy, endosurgery, minimally invasive surgery, bladder

\section{RESUMO}

Descreve-se a remoção de cálculos vesicais por cirurgia laparoscópica em três cães utilizando-se três portais (dois de $10 \mathrm{~mm}$ e um de $5 \mathrm{~mm}$ ) dispostos na linha média ventral e nas paredes abdominais direita e esquerda. Após a remoção das litíases, realizou-se sutura intracorpórea da parede vesical, em padrão contínuo simples, abrangendo as quatro camadas do órgão e em Lembert contínuo ou interrompido, incorporando a serosa e a muscular. Não houve complicações pós-operatórias. Um dos pacientes apresentou recidiva da doença, condição atribuída ao manejo dietético deficiente no pós-operatório. Esse paciente foi novamente submetido à cistotomia laparoscópica similar sem a ocorrência de complicações. A técnica proposta foi adequada e pode ser utilizada como alternativa para cistotomia por celiotomia no tratamento de litíases vesicais em cães.

Palavras-chave: cão, laparoscopia, endocirurgia, cirurgia minimamente invasiva, bexiga

\section{INTRODUCTION}

Cystotomy is the most common procedure to remove vesical calculi in small animals (Waldron, 1993; Dória et al., 2007). This surgical removal is indicated for obstructive lithiasis, except for those constituted of magnesium ammonium phosphate (Waldron, 1993), permitting uroliths analysis (Fossum, 2002).
Endoscopic surgery was initially used in urinary tract of dogs for diagnostics purposes (Grauer et al., 1983). Latter, laparoscopic surgery was used for treatments of different diseases such as dioctophimosis (Brun et al., 2002), hydronephrosis (Beck et al., 2000), retroflexion of the bladder (Rawlings et al., 2002), and colopexy (Brun et al., 2007). Despite the existence of different endoscopic cystotomy techniques (Rawlings et al., 2003; Rudd and

Recebido em 23 de junho de 2006 
Hendrickson, 1998), the treatment of vesical lithiasis by laparoscopic or laparoscopic-assisted surgery is not usual; therefore, only few scientific publications are available.

Rawlings et al. (2003) described the videoassisted surgery, which consists of the insertion of a cystoscope directly into the bladder by way of miniceliotomy, allowing for an in-depth inspection of the organ lumen. In that study, the dogs were positioned in Trendelenburg position and one $10-\mathrm{mm}$ trocar was introduced in the ventral midline. Similar trocar was introduced in the peritoneal cavity, in the ventral midline or paramedially, depending on the sex of the patients. The bladder was grasped by Babcock forceps and externalized from the cavity, allowing the introduction of the cystoscope through the organ wall with removal of the lithiasis. Although this technique has proven effective, it does not allow the removal of large calculi, for which laparoscopic cystotomy followed by intracorporeal suturing is recommended (Rudd and Hendrickson, 1998) or the open cystotomy (Waldron, 1993; Dória et al., 2007). The suitability of laparoscopic surgery in the management of cystic calculi in a cat was also reported (Brun et al., 2004).

Given that laparoscopic surgery has been more advantageous to humans than conventional surgery in terms of recovery and postoperative pain, esthetics and early return to normal activities (Monson et al., 1995; Solomon and Eyers, 1996), the aim of this study was to describe the laparoscopic technique to remove large vesical calculi in dogs.

\section{CASUISTIC}

Three female dogs diagnosed with bladder uroliths were submitted to laparoscopic cystotomy, with the consent of their owners. The first patient was a four-year-old Poodle Standard, not spayed, weighting $12 \mathrm{~kg}$. This dog had presented dysuria and hematuria for four months and abdominal pain during the physical exam, but it was afebrile. In the radiographic exam, three triangular calculi were visualized within the bladder. Ultrasonography confirmed the presence of the calculi. Values of hematocrit $(45 \%)$, serum proteins $(6.2 \mathrm{~g} / \mathrm{dl})$, urea $(60.0 \mathrm{mg} / \mathrm{dl})$, and creatinine $(0.85 \mathrm{mg} / \mathrm{dl})$ were in the normal range. Urine was collected by cystocentesis technique and confirmed hematuria, proteinuria, pyuria, bacteriuria, and bilirubinuria were confirmed. The urine $\mathrm{pH}$ and specific gravity were 7.5 and 1,015.0, respectively. The presence of cylinders (4/hpf) and epithelial cells (480/hpf) was detected by microscopy. Considering the size of the calculi, approximately $3.0 \mathrm{~cm}$, surgical removal was selected. Subsequent chemical analysis showed that they were constituted of carbonate, oxalate, calcium phosphate, and of magnesium ammonium phosphate. The animal did not demonstrate signs of further urolithiasis six months after surgery. But, eighteen months later, the patient returned with hematuria. The owner said that the animal had not been fed the special diet. Radiography showed two vesical calculi. At the request of the owner, repeat videolaparoscopic cystotomy was performed, using the same technique (that will be explained further), except for an interrupted Lembert pattern in the second bladder layer. In this surgery, the adhered omentum was seen in the ventral bladder wall and in the transverse abdominal muscle, where the $10 \mathrm{~mm}$ lateral trocar was positioned. The surgery lasted 60 minutes and there were no complications. In the post-operative period, the patient showed a primary cicatrisation and no signs of urolithiasis for 12 months.

The second patient was an adult mongrel bitch, weighing $8 \mathrm{~kg}$, with a small ventral abdominal hernia and no absorbable sutures in the ventral medium line. Hematuria and pollakiuria were detected in this dog. Ultrasonographically, similar images as in the first animal were obtained; but, the bitch had a single roundshaped calculus $(3.2 \times 2.7 \mathrm{~cm})$. The values of hematology were unremarkable. Leukocytosis $(16,300.0 / \mu \mathrm{l})$ was evident with neutrophilia $(12,980.0 / \mu \mathrm{l})$, eosinopenia $(1,151.0 / \mu \mathrm{l})$, and lymphopenia $(1,315.0 / \mu \mathrm{l})$. The alanine aminotransferase $(20.0 \mathrm{UI} / \mathrm{l})$, creatinine $(0.76 \mathrm{mg} / \mathrm{dl})$, and serum urea values $(40.0 \mathrm{mg} / \mathrm{dl})$ were in the physiological limits. Calculi analysis revealed carbonate, oxalate, calcium, magnesium, and ammonia. Sixteen months after surgery, the animal did not demonstrate signs or new urolithiasis.

The third patient was an $8 \mathrm{~kg}$ adult mongrel bitch, with incontinence and hematuria of unknown duration. Physical exam revealed a solid mass in the urinary bladder. In the radiographic exam, 
two rounded-shaped calculi were observed $(3 \mathrm{x}$ $2 \mathrm{~cm})$. Bladder wall thickening was also evident. Values of hematocrit $(39.1 \%)$, serum protein $(6.0 \mathrm{~g} / \mathrm{dl})$, creatinine $(0.56 \mathrm{mg} / \mathrm{dl})$, and alanine amino-transferase $(34.0 \mathrm{UI} / \mathrm{l})$ were in the physiological limits. Hematology demonstrated macrocytic anemia $(4,670,000.0 / \mu \mathrm{l}$; $\mathrm{VGM}=83.9 \mathrm{fl})$ and thrombocythemia $(141,000.0 / \mu 1)$. Leukocytosis was observed $(24,360.0 / \mu \mathrm{l})$ with neutrophilia $(21,437.0 / \mu \mathrm{l})$ and lymphopenia $(975.0 / \mu \mathrm{l})$. Urine was collected by catheter. Urinary $\mathrm{pH}$ and specific gravity were 7.0 and 1,024.0, respectively. Severe hematuria, proteinuria, pyuria, bacteriuria, and bilirubinuria were observed. The chemical analysis of the calculi demonstrated that they were constituted of carbonate, oxalate, calcium, magnesium, and ammonia. Ten months after surgery the dog had no recurrence.

The surgical procedure was performed under general anesthesia with isofluorane ${ }^{1}$ vaporized in $\mathrm{O}_{2}$ to $100 \%$, after anesthetic induction with propofol $^{2}, 10 \mathrm{mg} / \mathrm{kg}, \mathrm{IV}$, and fentanyl ${ }^{3}, 5 \mu \mathrm{g} / \mathrm{kg}$, IV. In all surgeries, the animals were positioned in horizontal recumbency. Ringer lactate ${ }^{4}$, $20 \mathrm{ml} / \mathrm{kg} / \mathrm{h}, \mathrm{IV}$, and fentanyl $(2 \mu \mathrm{g} / \mathrm{kg}, \mathrm{IV})$ were administered during surgical procedure. Thirty minutes before surgery, cephalothin ${ }^{5}, 30 \mathrm{mg} / \mathrm{kg}$, $\mathrm{IV}$, was given and the bladder was irrigated with $0.1 \%$ polyvinylpyrrolidone iodine solution ${ }^{6}$ using a Foley catheter.

An incision was made in the ventral medium line $2 \mathrm{~cm}$ distal to the umbilical scar. In the first patient, pneumoperitoneum with $\mathrm{CO}_{2}$ was created through a Veress needle inserted in the operative wound. In the other two animals, a $10 \mathrm{~mm}$ trocar was employed. One bitch had been previously undergone a celiotomy and presented small ventral abdominal hernia. The intracavitary pressure was stabilized at $12 \mathrm{mmHg}$ through the trocar positioned in the ventral medium line. Two more trocars were introduced via the flanks, one in the right lateral $(10 \mathrm{~mm})$ and the other in the left lateral $(5 \mathrm{~mm})$, creating a triangular disposition (Fig. 1).

\footnotetext{
${ }^{1}$ Isoflurane, Cristália - Itapira - Brazil.

${ }^{2}$ Diprivan, Cristália - Itapira - Brazil.

${ }^{3}$ Fentanil 0,05mg/ml, Cristália - Itapira - Brazil. .

${ }^{4}$ Ringer lactato; Cristália - Itapira - Brazil.

${ }^{5}$ keflin 1g, Eli Lilli do Brasil Ltda, São Paulo - Brazil.

${ }^{6}$ Riodeine; Rioquimica, São José do Rio Preto - Brazil.
}

A longitudinal incision in the ventral surface of the organ was made after grasping the bladder with Babcock forceps, in the first patient using a harmonic scalpel, and in the others by Metzenbaum scissors. The calculi were removed with Kelly or grasping forceps and placed in a specimen retrieval bag. After inspection of the interior of the bladder, the bladder wall was in closed two layers of buried sutures with 3-0 polyglycolic acid avoiding the mucous layer. In the first layer, the simple continuous pattern was used; and in the second layer, the suture was made with interrupted Lembert in the first dog (Fig. 2). In the other two animals, a continuous Lembert was employed.

The efficacy of the first suture layer was checked by filling the bladder with saline solution by a Foley catheter. An omental flap was placed over the vesical wound in the first patient; but in the others, omentum was sutured in the bladder with simple interrupted sutures.

The specimen retrieval bag was grasped with Kelly forceps and exteriorized from the abdominal cavity through the right trocar. An one-centimeter lengthening of the wound was necessary to break the calculus inside the tissue bag and then they were removed. After the drainage of $\mathrm{CO}_{2}$ from the cavity and trocar removal, the suture of the larger operative wounds (10mm trocars) was made in two layers, one in the parietal musculature and the other in the skin. The smaller wound $(5 \mathrm{~mm}$ trocar) was closed in a simple pattern. A Sultan pattern was used in the musculature; and in the skin an interrupted simple suture using 2-0 nylon was performed.

Postoperative care comprised antibiotics: cephalothin, (q8h, 7d), in the first two patients; and enrofloxacin ${ }^{7}(5 \mathrm{mg} / \mathrm{kg}, \mathrm{SC}, \mathrm{q} 24 \mathrm{~h}, 7 \mathrm{~d})$ in the third patient. In all animals, ketoprofen ${ }^{8}$ (2mg/kg, SC, q24h, 3d) was used. Cleaning of the operative wounds with saline solution was undertaken every 8 hours. To avoid the recurrence of urolithiasis, a special diet was indicated.

\footnotetext{
${ }^{7}$ Flotril 10\%, Schering-Plough, Rio de Janeiro - Brazil.
}

${ }^{8}$ Ketofen $1 \%$, Rhodis-Mérieux, Paulínia - Brazil. 


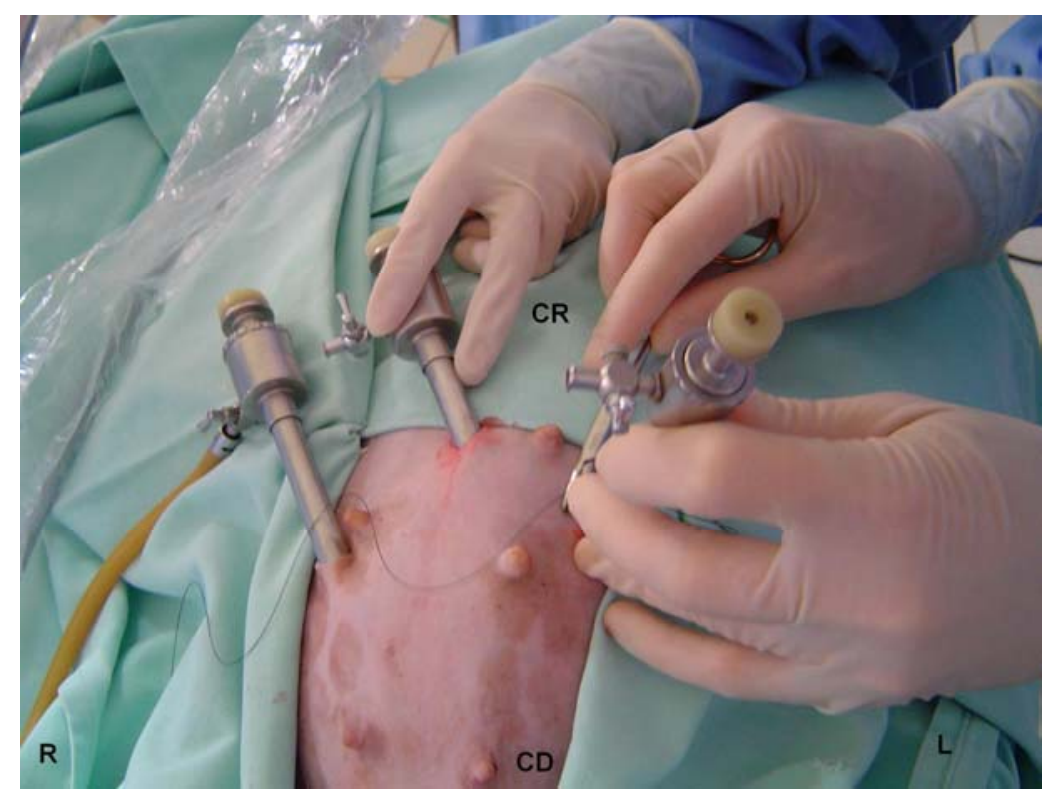

Figure 1. Triangular placement of trocars in laparoscopic cystotomy for the removal of bladder stones in dogs. $\mathrm{CR}=$ cranial; $\mathrm{CD}=$ caudal; $\mathrm{R}=$ right; $\mathrm{L}=$ left.

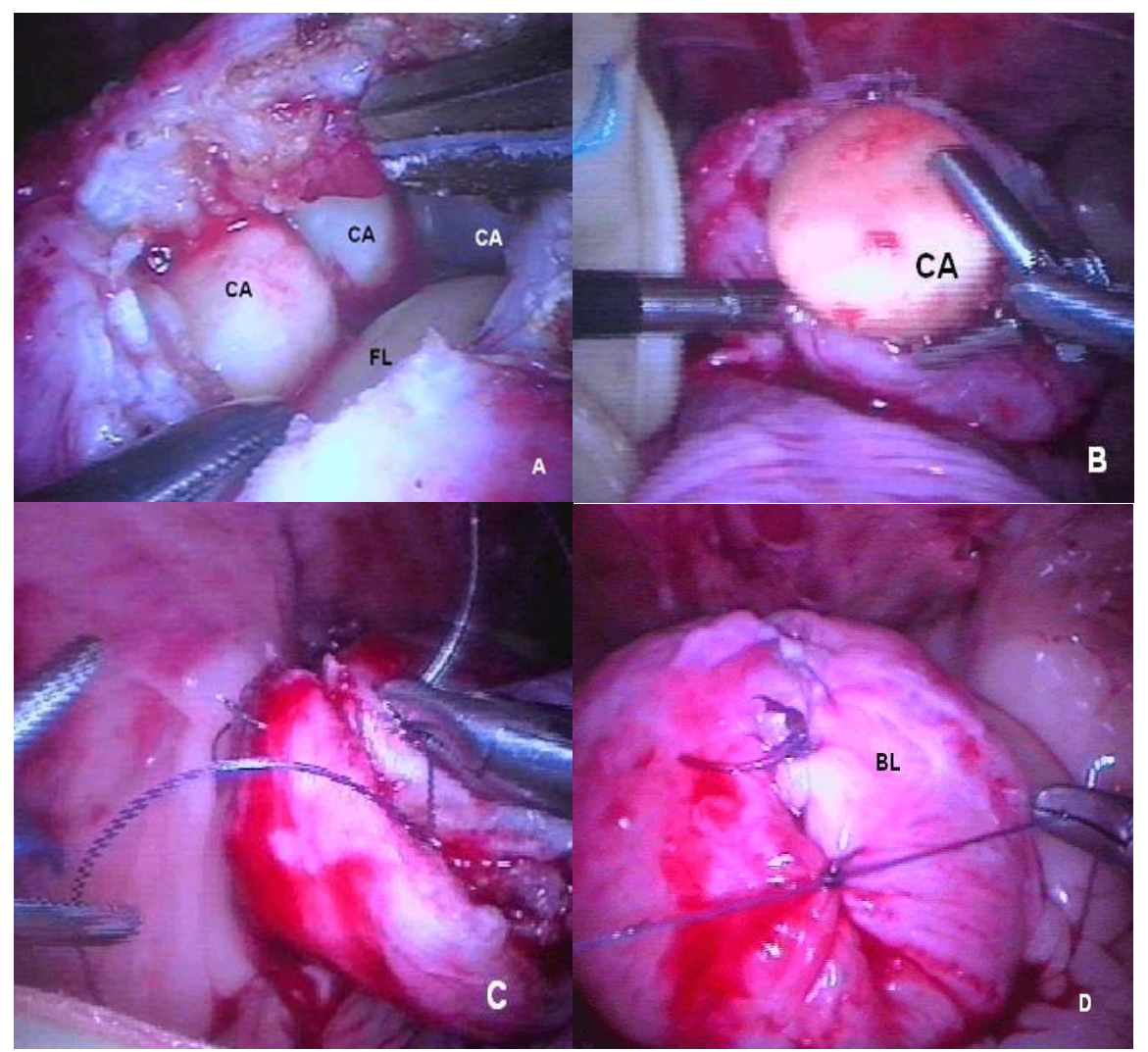

Figure 2. Laparoscopic technique for the removal of bladder stones in dogs. The sequence of surgical maneuvers is shown in the first patient. A) Surgical wound involving the four layers of the bladder, showing three calculi (CA); $\mathrm{FL}=$ Foley cateter. The extremities of grasps touching the thickness wall of the bladder. B) Removal of the calculi before their placement into the retrieval bag. C) Application of the first suture layer in simple, continuous pattern. D) Application of the second suture layer for the occlusion of the bladder; BL= bladder. In this patient, it was used an interrupted Lembert suture with 3-0 polyglycolic acid and continuous Lembert with the same thread. 
No complication during the operative and postoperative periods was observed. The number and position of the trocars and the instrumentation were effective for the procedures. The time necessary to remove all the uroliths in each patient was, respectively: 120,147 , and $130 \mathrm{~min}$.

All the patients were discharged three days after surgery. A special commercial $\operatorname{diet}^{9}$ was prescribed after surgery. The Foley catheters were removed on the first or second postoperative day. All the patients ate solid food from the first postoperative day. After seven days, the skin sutures were removed and the wounds healed uneventfully.

\section{DISCUSSION}

In this work, the use of laparoscopic surgery to remove the lithiasis was preferred considering the better results in relation to the conventional surgery, mainly the ones related to the postoperative period (Monson et al., 1995; Flowers et al., 1997; Liem et al., 1997).

The technique of Rawlings et al. (2003) was chosen to remove the calculi because of their large size, differently from what was indicated by Rudd and Hendrickson (1998), in relation to the employment of just a simple continuous suture for the closure of the bladder after laparoscopic cystotomy, in all three cases. A simple continuous with Lembert suture patterns were selected, as suggested by Waldron (1993) and Fossum (2002).

The continuous horizontal mattress could be used, as mentioned by Rudd and Hendrickson (1998); but, in this study the authors opted for the continuous simple suture, because it promotes a better occlusion for the water and the air (Toombs and Bauer, 1993). Differently from Edwards III et al. (1995), that used linear stapler in the occlusion of equine urinary bladder, in the three dogs of this study, the authors opted for the intracorporeal suture, aiming to decrease the operative costs and considering the suggestion that intravesical staples could induce a stone formation (Edwards III et al., 1995, Rawlings et al., 2003).

${ }^{9}$ Urinary, Royal Canin, Descalvado - Brazil.
The animals of this study were maintained in ventral recumbency without inclination though the Trendelenberg positioning could have facilitated laparoscopy. Respiratory and circulatory dysfunctions were not associated with the adopted position; but be could with the inclination of the patient (Allen, 1996).

The omentopexy followed what Rawlings et al. (2003) performed and it is based in the possibility of helping the local cicatrisation and decreasing the risk of peritonitis, because the omentum hinders the suture line, promoting neovascularization, granulation tissue, controlling infection, and helping lymphatic drainage (Ellison, 1989; Thornoton and Barbul, 1997).

According to Rudd and Hendrickson (1998), the position of the intravesical endoscope during surgery facilitated the visualization of the vesical mucosa and the proximal urethra in all patients, aiding disposal of remaining calculus particles, a common mistake associated with the surgical treatment of urolithiasis (Fossum, 2002).

\section{CONCLUSIONS}

As the only alteration in the patients of this study was the recurrence in the first patient, without correlation with the procedure, the proposed technique can be used as alternative to the cystotomy for celiotomy in treatment of bladder calculi in dogs.

\section{ACKNOWLEDGEMENTS}

To the collaborators: Daniela Scandolara Gonçalves, Eduardo Santiago Ventura de Aguiar, Carlos Afonso de Castro Beck, and Ricardo Zanella.

\section{REFERENCES}

ALLEN, P.D. Anesthesia for minimally invasive surgery. In: LOUGHLIN K.R.; BROOKS D.C. (Eds). Principles of endosurgery. Cambridge: Backwell Science, 1996. p.54-71.

BECK, C.A.C.; PIPPI, N.L.; BRUN, M.V. et al. Nefrectomia laparoscópica em cães com hidronefrose unilateral. Cien. Anim. Bras., v.1, p.180, 2000. 
BRUN, M.V.; BARCELLOS, H.H.A.; OLIVEIRA, R.P. et al. Tratamento de cistolitíase em gata por cirurgia laparoscópica. Braz. J. Vet. Res. Anim. Sci., v.41, p.93, 2004.

BRUN, M.V.; BECK, C.A.; MARIANO, M.B. et al. Nefrectomia laparoscópica em cão parasitado por Dioctophyma renale - relato de caso. Arq. Cien. Vet. Zool. UNIPAR, v.5, p.145-152, 2002.

BRUN, M.V.; GUIMARÃES, L.D.; BARCELOS, H.H.A. et al. Colopexia laparoscópica com retalho de tela de polipropileno. Arq. Bras. Med. Vet. Zootec., v.59, p.119-126, 2007.

DÓRIA. R.G.S.; CANOLA, P.A.; DIAS, D.P.M. et al. Técnicas cirúrgicas para urolitíase obstrutiva em pequenos ruminantes: relato de casos. Arq. Bras. Med. Vet. Zootec., v.59, p.1425-1432, 2007.

EDWARDS III, R.B.; DUCHARME， N.G.; HACKETT, R.P. Laparoscopic repair of a bladder rupture in a foal. Vet. Surg., v.24, p.6063, 1995.

ELLISON, G.W. Wound healing in the gastrointestinal tract. Sem. Vet. Med. Surg. Small Anim., v.4, p.287-293, 1989.

FLOWERS, J.L.; JACOBS, S.; CHO, E. et al. Comparison of open and laparoscopic live donor nephrectomy. Ann. Surg., v.1226, p.483-490, 1997.

FOSSUM, T.H. Cirurgia da bexiga e da uretra. In: Cirurgia de pequenos animais. São Paulo: Roca, 2002. p.534-570.

GRAUER, G.F.; TWEDT, D.C.; MERO, K.N. Evolution of laparoscopic for obtaining renal biopsy specimens from dogs and cats. J. Am. Vet. Med. Assoc., v.183, p.677-679, 1983.
LIEM, M.S.L.; GRAAF, Y.V.D.; STEENSEL, C.J.V. et al. Comparison of conventional anterior surgery and laparoscopic surgery for inguinalhernia repair. N. Engl. J. Med., v.36, p.15411547, 1997.

MONSON, J.R.T.; HILL, A.D.K.; DARZI, A. Laparoscopic colonic surgery. Br. J. Surg., v.82, p.150-157, 1995.

RAWLINGS, C.A.; HOWERT, E.W.; MAHAFFEY, M.B. Laparoscopic-assisted cystopexy in dogs. Am. J. Vet. Res., v.9, p.12261231, 2002.

RAWLINGS, C.A.; MAHAFFEY, M.B.; BARSANTI, J.A. et al. Use of laparoscopicassisted cystoscopy for removal of urinary calculi in dogs. J. Am. Vet. Med. Assoc., v.222, p.759-761, 2003.

RUDD, R.G.; HENDRICKSON, D.A. Minimally invasive surgery of the urinary system. In: FREEMAN, L.J. (Ed.). Veterinary endosurgery. St. Louis: CV Mosby, 1998. p.226-236.

SOLOMON, M.J.; EYERS, A.A. Laparoscopic rectopexy using mesh fixation with a spiked chromium staple. Dis. Colon Rectum, v.39, p.279-384, 1996.

TOOMBS, J.P.; BAUER, M.S. Basic operative techniques. In: SLATTER, D. (Ed.). Textbook of small animal surgery. 2.ed. Philadelphia: W.B. Saunders, 1993. p.168-191.

THORNTON, F.J.; BARBUL, A. Cicatrização no trato gastrointestinal. In: BARBUL, A. (Ed). Cicatrização das feridas. Rio de Janeiro: Interlivros, 1997. p.547-570.

WALDRON, D.R. Urinary bladder. In: SLATTER, D. (Ed). Textbook of small animal surgery. 2.ed. Philadelphia: W.B. Saunders, 1993. p.1451-1473. 